\title{
Hak Cipta dalam Perspektif Hukum Islam
}

\author{
Supeno ${ }^{1}$ \\ Fakultas Hukum, Universitas Batanghari, Jalan Slamet Riyadi Broni Kota Jambi \\ (0741) 65351 \\ msasyabani@gmail.com
}

\begin{abstract}
Abstrak
Hak atas Kekayaan Intelektual (HKI) merupakan salah satu hak yang telah mendapatkan perlindungan secara hukum di Indonesia, ada beberapa peraturan perundang-undangan yang mengatur tentang hak-hak yang termasuk dalam ruang lingkup kekayan intelektual seperti hak cipta, hak paten, hak merek, hak rahasia dagang dan sebagainya. Yang perlu diketahui lebih mendalam adalah bagaimana hak cipta dalam perspektif hukum Islam karena Indonesia sebagai negara terbesar menganut agama Islam akan sangat mempengaruhi pemahaman dan kesadaran penduduk Indonesia akan pentingnya perlindungan terhadap hak atas kekayaan intelektual.
\end{abstract}

Kata kunci: Hak Cipta, hukum Islam

\begin{abstract}
Intellectual property (HKI) is one of the rights that have been getting protection by law in Indonesia, there are some regulations that govern on rights that are included in the scope of intellectual kekayan as copyrights, patent rights, trademark rights, trade secret rights and so on. To know more deeply is how copyright in the perspective of Islamic law because Indonesia as the country's largest Islamic religion will greatly affect the understanding and awareness of the importance of the protection of the population of Indonesia against intellectual property.
\end{abstract}

Keywords: copyright, the law of Islam

\section{PENDAHULUAN}

Manusia sebagai makhluk homo sapien diciptakan oleh Allah SWT dianugrahi kemampuan secara fisik dan rohani, salah satu perbedaan manusia dengan makhluk ciptaan Allah yang lainnya adalah bahwa manusia dibekali nafsu dan akal fikiran sehingga manusia adalah makhluk yang cerdas yang memiliki kreasi yang tinggi dalam menjalankan kehidupannya dan memiliki kemampuan untuk menguasai sesuatu. Dengan bekal kemampuan yang telah diberikan oleh Allah SWT tersebut maka manusia mampu untuk melakukan sesuatu, membuat kreasi baru yang bertujuan untuk memenuhi kebutuhan hidupnya sehingga banyak sekali karya-karya yang telah dihasilakan oleh manusia yang dapat dimanfaatkan baik oleh yang bersangkutan maupun oleh orang banyak. Karena hasil karya seseorang banyak digunakan oleh orang lain bahkan dapat menghasilkan sesuatu yang bernilai ekonomis maka mulai berkembang upaya untuk mempertahankan apa yang sudah dihasilkannya. Oleh karenanya timbul gagasan-gagasan untuk melindungi hasil kreasi intelektual seseorang dalam bentuk perlindungi terhadap Hak atas Kekayaan Intelektual (HKI)

\footnotetext{
${ }^{1}$ Dosen Fakultas Hukum Universitas Batanghari
} 
Secara historis, peraturan perundang-undangan di bidang HKI di Indonesia telah ada sejak tahun 1840-an. Pemerintah Kolonial Belanda memperkenalkan undang-undang pertama mengenai perlindungan HKI pada tahun 1844. Selanjutnya, Pemerintah Belanda mengundangkan UU Merek (1885), UU Paten (1910), dan UU Hak Cipta (1912). Indonesia yang pada waktu itu masih bernama Netherlands East-Indies telah menjadi anggota Paris Convention for the Protection of Industrial Property sejak tahun 1888 dan anggota Berne Convention for the Protection of Literary and Aristic Works sejak tahun 1914. Pada jaman pendudukan Jepang yaitu tahun 1942 s.d. 1945, semua peraturan perundangundangan di bidang HKI tersebut tetap berlaku.

Istilah hak cipta (copyright) sebagai bagian dari rezim hak kekayaan intelektual (intellectual property right) mulai dipergunakan dalam Kongres Kebudayaan Indonesia ke-2 yang diselenggarakan di Bandung bulan Oktober 1951. ${ }^{2}$ Pada tahun 1953 Menteri Kehakiman RI mengeluarkan pengumuman yang merupakan perangkat peraturan nasional pertama yang mengatur tentang paten, yaitu Pengumuman Menteri Kehakiman No. J.S. 5/41/4, yang mengatur tentang pengajuan semetara permintaan paten dalam negeri, dan Pengumuman Menteri Kehakiman No. J.G. 1/2/17 yang mengatur tentang pengajuan sementara permintaan paten luar negeri.

Pada tanggal 12 April 1982 Pemerintah mengesahkan UU No.6 tahun 1982 tentang Hak Cipta ( UU Hak Cipta 1982) untuk menggantikan UU Hak Cipta peninggalan Belanda. Pengesahan UU Hak Cipta 1982 dimaksudkan untuk mendorong dan melindungi penciptaan, penyebarluasan hasil kebudayaan di bidang karya ilmu, seni dan sastra serta mempercepat pertumbuhan kecerdasan kehidupan bangsa. Tahun 1986 dapat disebut sebagai awal era modern sistem HKI di tanah air. Pada tanggal 23 Juli 1986 Presiden RI membentuk sebuah tim khusus di bidang HKI melalui Keputusan No. 34/1986 (Tim ini lebih dikenal dengan sebutan Tim Keppres 34). Tugas utama Tim Keppres 34 adalah mencangkup penyusunan kebijakan nasional di bidang HKI, perancangan peraturan perundangundangan di bidang HKI dan sosialisasi sistem HKI di kalangan instansi pemerintah terkait, aparat penegak hukum dan masyarakat luas. Tim Keppres 34 selanjutnya membuat sejumlah terobosan, antara lain dengan mengambil inisiatif baru dalam menangani perdebatan nasional tentang perlunya sistem paten di tanah air. Setelah Tim Keppres 34 merevisi kembali RUU Paten yang telah diselesaikan pada tahun 1982, akhirnya pada tahun 1989 Pemerintah mengesahkan UU Paten.

Pada tahun 1988 berdasarkan Keputusan Presiden No. 32 di tetapkan pembentukan Direktorat Jendral Hak Cipta, Paten dan Merek (DJ HCPM) untuk mengambil alih fungsi dan tugas Direktorat Paten dan Hak Cipta yang merupakan salah satu unit eselon II di lingkungan Direktorat Jenderal Hukum dan Perundangundangan, Departemen Kehakiman. Pada tanggal 15 April 1994 Pemerintah RI menandatangani Final Act Embodying the Result of the Uruguay Round of Multilateral Trade Negotiations, yang mencakup Agreement on Trade Related Aspects of Intellectual Property Rights(Persetujuan TRIPS). Dalam upaya untuk menyelaraskan semua peraturan perundang-undangan di bidang HKI dengan Persetujuan TRIPS, pada tahun 2001 Pemerintah Indonesia mengesahkan UU No. 14 tahun 2001 tentang Paten, dan UU No. 15 tahun 2001 tentang Merek. Kedua UU ini menggantikan UU yang lama di bidang terkait. Pada pertengahan tahun

\footnotetext{
${ }^{2}$ Ramdlon Naning, Perihal Hak Cipta, Liberty, Yogyakarta, 1982, hal.1
} 
2002 tentang Hak Cipta yang menggantikan UU yang lama, saat ini hak cipta diatur dalam Undang-Undang Nomor 28 Tahun 2014. Perkembangan di bidang perdagangan, industri dan investasi yang sangat cepat sehingga memerlukan peningkatan perlindungan bagi pencipta dan pemilik hak terkait dengan tetap memperhatikan kepentingan masyarakat luas. ${ }^{3}$ Dalam penjelasan Undang-Undang Nomor 28 Tahun 2014 dinyatakan bahwa perlindungan hak cipta dilakukan dengan waktu lebih panjang sejalan dengan penerapan aturan di berbagai negara sehingga jangka waktu perlindungan hak cipta di bidang tertentu diberlakukan selama hidup pencipta ditambah 70 (tujuh puluh) tahun setelah pencipta meninggal.

Sebelumnya telah dinyatakan bahwa ditetapkannya undang-undang hak cipta karena semakin maraknya pelanggaran hak cipta yang dapat membahayakan kehidupan sosial dan menghancurkan kreativitas masyarakat. Contoh pelanggaran Hak Cipta yaitu adanya pelanggaran Hak Cipta yang dilakukan oleh negara Malaysia. Setelah gagal mengklaim lagu Rasa Sayange, Malaysia mencoba mengklaim kesenian yang lain yaitu kesenian rakyat Jawa Timur: Reog Ponorogo yang diklaim Malaysia sebagai kesenian mereka. Kesenian Wayang Kulit yang mereka klaim tidak mengubah nama "Reog", mungkin karena diikuti nama daerah Ponorogo maka namanya diubah menjadi "Tarian Barongan". Padahal wujud Reog itu bukan naga seperti Barongsai tapi wujud harimau dan burung merak yang sama seperti Reog Ponorogo. Malaysia kesulitan mencari nama baru sehingga memilih yang mudah saja, yaitu Tarian Barongan. Bukan itu saja, kisah dibalik tarian itupun diubah. Hal ini sama seperti ketika Malaysia mengubah lirik lagu Rasa Sayange. Kalau saja mereka menyertakan informasi dari mana asal tarian tersebut maka tidak akan ada yang protes.

Padahal apa susahnya mencantumkan nama asli dan bangsa pemiliknya. Seperti yang mereka lakukan pada kesenian Kuda Kepang yang kalau di Indonesia lebih dikenal dengan nama Kuda Lumping. Malaysia mencantumkan nama asal kesenian Kuda Kepang dari Jawa. Kenapa tidak dilakukan pada kesenian yang lain seperti Reog Ponorogo, Wayang Kulit, Batik, Angklung, Rendang dan lainlain.

Malaysia telah melanggar Hak Cipta yaitu menggunakan budaya asli Indonesia dengan mengganti nama, cerita, namun kebudayaan tersebut sesungguhnya berasal dari Indonesia. Pelanggaran Hak Cipta yang telah dilakukan oleh Negara Malaysia dapat dikenakan tindak pidana ataupun perdata. Sebenarnya, hal ini dapat dicegah jika Malaysia mencantumkan nama asli dan bangsa pemilik dari kebudayaan yang dipertunjukkan.

Dalam perspektif yang berbeda dapat diungkapkan bahwa Indonesia sebagai negara memiliki jumlah penduduk yang besar dan penduduknya mayoritas Islam memiliki potensi yang sangat besar tumbuh kembangnya karya cipta, untuk mencapai tujuan tersebut perlu ditingkatkan kesadaran bagi masyarakat Indonesia begitu pentingnya pengakuan dan perlindungan hak cipta, salah satu pendekatan yang dapat dilakukan adalah memberikan edukasi dan pemahaman bagaimana Islam memandang hak cipta, yang patut disadari bahwa penduduk Indonesia adalah masyarakat yang religius dan lebih mudah menerima jika sesuatu disandarkan kepada hukum Islam. Untuk itu perlu dilakukan pemahaman terhadap hak cipta dalam perspektif hukum Islam dan pandangan Islam terhadap hak cipta,

${ }^{3}$ Muhammad Firmansyah, Tata Cara Mengurus HAKI, Visi Media, Jakarta, 2008, hal.9 
dalam konteks tersebut umat Islam dapat diposisikan baik sebagai pencipta maupun sebagai pengguna karya orang lain.

\section{METODE PENULISAN}

Metode penulisan yang penulis gunakan adalah metode penulisan Deduktif yaitu dengan cara pemaparan secara umum untuk mendapatkan kesimpulan secara khusus tentang Hak Cipta dalam perspektif Islam, tipe yang digunakan adalah yuridis normatif yang bersifat deskriptif analitik yaitu untuk memperoleh gambaran secara menyeluruh dan mendalam dan melakukan analisis terhadap permasalahan yang dibahas.

Untuk menjawab permasalahan maka dilakukan pengumpulan bahan hukum melalui studi dokumen (studi kepustakaan), bahan-bahan tersebut kemudian diinventarisasi dan diidentifikasi, teknis analisis dilakukan secara interpretasi, yaitu bahan hukum diinterpretasikan dan dijabarkan dengan mendasarkan pada suatu norma dan teori hukum yang berlaku, penarikan kesimpulan dilakukan dengan menggunakan metode penalaran secara deduktif.

\section{HASIL DAN PEMBAHASAN}

Konsep hak cipta di Indonesia merupakan terjemahan dari konsep copyright dalam bahasa Inggris (secara harafiah artinya "hak salin"). Copyright ini diciptakan sejalan dengan penemuan mesin cetak. Menurut OK Saidin dalam bukunya yang berjudul Aspek Hukum Hak Kekayaan Intelektual menyetakan bahwa: Hak cipta meliputi hak tunggal si pencipta untuk membuat, menerbitkan, dan memberi kuasa untuk menerbitkan dan membuat terjemahan daripada karya yang dilindungi perjanjian ini. ${ }^{4}$

Hak cipta merupakan hak yang dimiliki seseorang karena telah menciptakan sesuatu dan orang tersebut berkuasa atas ciptaannya untuk menggunakan, menerbitkan dan melindungi hasil karyanya. Perlindungan akan hasil karya seseorang merupakan hal penting dalam hubungannya dengan penghormatan terhadap hak-hak manusia dan kemerdekaan individu untuk menciptakan sesuatu, Menurut Satjipto Rahardjo: HKI termasuk hak cipta adalah suatu institusi yang muncul dari suatu komunitas yang sangat sadar akan hak-hak dan kemerdekaan individu, bukan dari dalam suatu komunitas lebih berbasis komunitas ${ }^{5}$

Oleh karena itu pemerintah untuk melindungi hak-hak individu dalam karya intelektual telah mengesahkan Undang-Undang Nomor 19 Tahun 2002 Tentang Hak Cipta, dengan diundangkannya undang-undang tersebut diharapkan inovasi dalam karya intelektual terutama hak cipta dapat meningkat yang pada akhirnya dapat meningkatkan ekonomi dan kemaslahatan bagi orang banyak.

Hak Cipta adalah Hak eksklusif bagi Pencipta atau penerima hak untuk mengumumkan dan memperbanyak ciptaannya atau memberikan izin untuk itu dengan tidak mengurangi pembatasan-pembatasan menurut peraturan perundangundangan yang berlaku. ${ }^{6}$ Hak cipta dapat juga memungkinkan pemegang hak tersebut untuk membatasi penggandaan tidak sah atas suatu ciptaan, pada

${ }^{4}$ OK. Saidin, Aspek Hukum Hak Kekayaan Intelektual, Raja Grafindo Persada, Jakarta, 2006, hal. 219

${ }^{5}$ Satjipto Rahardjo, Aspek Sosio-Kultural dalam Pemajuan HKI, makalah dalam seminar nasional penegakan hokum HKI dalam konteks perlindungan ekonomi usaha kecil dan menengah, Semarang, 25 Nopember 2000 
umumnya hak cipta memiliki masa berlaku tertentu yang dibatasi oleh undangundang. Ciptaan adalah hasil setiap karya pencipta yang menunjukkan keaslian dalam lapangan ilmu pengetahuan, seni atau sastra, ${ }^{7}$ sedangkan pencipta adalah seseorang atau beberapa orang secara bersama-sama yang atas inspirasinya melahirkan suatu ciptaan berdasarkan kemampuan pikiran, imajinasi, kecekatan, ketrampilan atau keahlian yang dituangkan dalam bentuk yang khas dan bersifat pribadi. $^{8}$

Undang-undang Hak Cipta memberikan hak kepada individu untuk melindungi hasil ciptaannya serta melarang orang lain untuk memanfaatkan ciptaan tersebut kecuali dengan izinnya. Negara harus menjaga hak tersebut dan mengenakan hukuman bagi setiap orang yang melanggarnya dengan hukuman penjara sehingga puluhan tahun, baik ketika penciptanya masih hidup atau telah mati. Undang-undang yang dilegalisasi juga mesti mencakup undang-undang perlindungan bagi perusahaan-perusahaan pemegang hak paten. Maksud dari karya cipta adalah pemikiran atau pengetahuan yang diciptakan oleh seseorang dan belum ditemukan oleh orang lain sebelumnya. Bagian terpenting dari karyakarya cipta tersebut adalah pengetahuan yang boleh dimanfaatkan dalam perindustrian serta produksi barang dan jasa (usaha) dan apa yang sekarang ini disebut sebagai "teknologi".

Sebagaimana dijelaskan diatas bahwa ciptaan adalah hasil setiap karya pencipta yang menunjukkan keaslian dalam lapangan ilmu penetahuan, seni atau sastra (Pasal 1 butir 3). Pemegang hak cipta adalah pencipta sebagai pemilik hak cipta atau pihak (Pasal 1 butir 4). Dari ketentuan diatas terlihat, bagi seseorang yang telah memenuhi syarat yang telah ditentukan oleh UUHC, mempunyai hak khusus terhadap satu hasil karya cipta. Sebagai hak khusus pencipta atau pemegang hak cipta mempunyai hak enam diantaranya ialah:

1. Memperbanyak Ciptaanya, artinya pencipta atau pemegang hak cipta dapat menambah jumlah ciptaan dengan perbuatan yang sama, hampir sama atau menyerupai ciptaan-ciptaan tersebut dengan mempergunakan bahan-bahan yang sama termasuk mengalih wujudkan ciptaan.

2. Mengumumkan Ciptaan, artinya pencipta atau pemegang hak cipta dapat menyiarkan dengan menggunakan alat apapun, sehingga ciptaan dapat didengar, dibaca atau dilihat oleh orang lain.

3. Memperbanyak haknya, artinya hak cipta sebagai hak kebendaan, maka pencipta atau pemegang hak cipta dapat menggugat pihak yang melanggar hak ciptaannya.

Hak cipta ada dua, yaitu:

1. Hak eksklusif

Beberapa hak eksklusif yang umumnya diberikan kepada pemegang hak cipta adalah hak untuk:

a. membuat salinan atau reproduksi ciptaan dan menjual hasil salinan tersebut (termasuk, pada umumnya, salinan elektronik),

b. mengimpor dan mengekspor ciptaan,

c. menciptakan karya turunan atau derivatif atas ciptaan (mengadaptasi ciptaan), 
d. menampilkan atau memamerkan ciptaan di depan umum,

e. menjual atau mengalihkan hak eksklusif tersebut kepada orang atau pihak lain.

Yang dimaksud dengan "hak eksklusif" dalam hal ini adalah bahwa hanya pemegang hak ciptalah yang bebas melaksanakan hak cipta tersebut, sementara orang atau pihak lain dilarang melaksanakan hak cipta tersebut tanpa persetujuan pemegang hak cipta.

Konsep tersebut juga berlaku di Indonesia. Di Indonesia, hak eksklusif pemegang hak cipta termasuk "kegiatan menerjemahkan, mengadaptasi, mengaransemen, mengalihwujudkan, menjual, menyewakan, meminjamkan, mengimpor, memamerkan, mempertunjukkan kepada publik, menyiarkan, merekam, dan mengkomunikasikan ciptaan kepada publik melalui sarana apapun.

Selain itu, dalam hukum yang berlaku di Indonesia diatur pula "hak terkait", yang berkaitan dengan hak cipta dan juga merupakan hak eksklusif, yang dimiliki oleh pelaku karya seni (yaitu pemusik, aktor, penari, dan sebagainya), produser rekaman suara, dan lembaga penyiaran untuk mengatur pemanfaatan hasil dokumentasi kegiatan seni yang dilakukan, direkam, atau disiarkan oleh mereka masing-masing. Sebagai contoh, seorang penyanyi berhak melarang pihak lain memperbanyak rekaman suara nyanyiannya.

Hak-hak eksklusif yang tercakup dalam hak cipta tersebut dapat dialihkan, misalnya dengan pewarisan atau perjanjian tertulis,pemilik hak cipta dapat pula mengizinkan pihak lain melakukan hak eksklusifnya tersebut dengan lisensi, dengan persyaratan tertentu.

2. Hak ekonomi dan hak moral

Banyak negara mengakui adanya hak moral yang dimiliki pencipta suatu ciptaan, sesuai penggunaan Persetujuan TRIPs WTO (yang secara inter alia juga mensyaratkan penerapan bagian-bagian relevan Konvensi Bern). Secara umum, hak moral mencakup hak agar ciptaan tidak diubah atau dirusak tanpa persetujuan, dan hak untuk diakui sebagai pencipta ciptaan tersebut.

Hak cipta di Indonesia juga mengenal konsep "hak ekonomi" dan "hak moral". Hak ekonomi adalah hak untuk mendapatkan manfaat ekonomi atas ciptaan, sedangkan hak moral adalah hak yang melekat pada diri pencipta atau pelaku (seni, rekaman, siaran) yang tidak dapat dihilangkan dengan alasan apa pun, walaupun hak cipta atau hak terkait telah dialihkan. Hak moral adalah hak yang melekat pada diri pencipta atau pelaku yang tidak dapat dihilangkan atau dihapus tanpa alasan apapun, walaupun hal cipta atau hak terkait telah dialihkan. ${ }^{9}$ Contoh pelaksanaan hak moral adalah pencantuman nama pencipta pada ciptaan, walaupun misalnya hak cipta atas ciptaan tersebut sudah dijual untuk dimanfaatkan pihak lain.

Al Qur'an dan al Hadist telah meletakkan ilmu pengetahuan sebagai sebuah instrumen yang sangat tinggi nilainya bagi manusia, manusia dituntut untuk menggunakan akal. Semua ini menunjukkan aktivitas intelektual karena sangat pentingnya ilmu itu maka mengajarkan dan menyebarkan ilmu menjadi sebuah keharusan dalam sistem sosial Islam.

Agama Islam melalui Nabi Muhammad Shalallahu Alaihi Wassalam menjadi penutup bagi syariat Allah yang diturunkan ke muka bumi, Allah

\footnotetext{
${ }^{9}$ Lihat penjelasan UU Nomor 19 Tahun 2002 Tentang Hak Cipta
} 
meletakkan di dalamnya unsur transender dan kekekalan, serta unsur elastisitas dan evolusi secara bersamaan, ${ }^{10}$ Syariat Islam transenden dalam tujuantujuannya, namun elastik dalam cara dan metode-metode untuk mencapai tujuan, syariat Islam transender dalam ushul (dasar) dan kulliyyaat (umum), namun elastic dalam furu' (cabang) dan juziyyat (particular). Sedangkan yang menjadi prinsip-prinsip hukum Islam adalah sebagai berikut:

a. Tauhidullah, bahwa semua paradigm berfikir yang digunakan untuk menggali kandungan ajaran Islam yang termuat dalam Al-Qur'an dan AlHadist dalam konteks ritual maupun sosial harus bertitik tolak dari nilainilai ketauhidan

b. Insaniyah (prinsip kemanusiaan) memuliakan manusia dan memberikan manfaat serta menghilangkan kemudharatan bagi manusia

c. Tasamuh (toleransi)

d. Ta'awun (tolong menolong)

e. Silaturrahmi baina al-nas (menyambung persaudaraan antar manusia)

f. Keadilan

g. Kemaslahatan ${ }^{11}$

Semua prinsip tersebut merujuk pada lima tujuan Syariat Islam yang dijabarkan di bawah ini yaitu:

a. Memelihara agama

b. Memelihara akal

c. Memelihara jiwa

d. Memelihara keturunan

e. Memelihara harta kekayaan ${ }^{12}$

Di dalam Islam diperintahkan untuk memelihara harta kekayaan yang dimiliki artinya harus melindungi harta kekayaan dari gangguan orang lain dalam bentuk perampasan, pencurian dan sebagainya, sebagai salah satu kekayaan yang dimiliki oleh manusia adalah kekayaan intelektual dalam bentuk hak cipta. Allah tidak menurunkan Al-Qur'an untuk menjadi satu kitab yang menerangkan kepada manusia mengenai teori-teori ilmiah, problem-problem seni serta warna pengetahuan. ${ }^{13}$, akan tetapi Al-Qur'an tidak kering dari nilai-nilai ilmu pengetahuan, teknologi, seni dan sastra oleh karena itu hak cipta dalam Islam dapat ditelusuri melalui penghargaan terhadap manusia yang berilmu pengetahuan sebagaimana yang tertuang dalam Surat Az Zumar ayat 9 "adakah sama orangorang yang mengetahui dengan orang-orang yang tidak mengetahui?".

Oleh karena itu, Islam tidak mengenal monopoli ilmu pengetahuan, memproteksi sebuah ilmu agar orang lain tidak mengetahuinya. Islam menganjurkan dan menfasilitasi agar tersebarnya ilmu pengetahuan. Walau demikian, fiqh islam klasik secara ekplisit tidak dikenal adanya hak kekayaan intelektual atau benda yang abstrak.

Dalam kitab Kaysf al Asror, imam Abu Qosim menjelaskan hak seseorang adalah setiap hak yang dapat dilihat dari berbagai sudut pandang. Dalam penjelasan hak ini, imam Ahmad memiliki sebuah pendapat bahwa"seseorang tidak boleh menyalin hadis dalam kertas, ketika ia menemukan sebuah kertas yang

\footnotetext{
${ }^{10}$ Yusuf Al-Qardhawi, Islam dan Sekurelisme, Pustaka Setia, Bandung, 2006, hal. 186

${ }^{11}$ Beni Ahmad Saebani, Filsafat Hukum Islam, Pustaka Setia, Bandung, 2008, hal. 123

12 Ibid, hal. 121

${ }^{13}$ Mahmud Syaltut, Tafsir Al-Qur'an, Dar Al-Qalam, Kairo, hal. 21
} 
terdapat, kecuali bila diizinkan oleh pemiliknya". Walupun hukum ini lahir dalam konteks adab dan tasawuf, tetapi hal ini merupakan bentuk legitimasi terhadap penguasaan pemilik tulisan atas tulisannya. Hal ini dapat diartikan bahwa sebuah karya adalah hak milik pencipta sebagai hasil dari jerih payah intelektualiasnya. kemudian timbul pertanyaan terkait hak cipta sebuah karya, Apakah ia merupakan hak yang bersifat materi, ataukah immateri yang terlepas dari sisi-sisi komersial.

Untuk menjawab masalah diatas, guru besar Ushul Fiqih Universitas Damaskus, Dr.Said Romadlon al Buthi, menjelaskan bahwa "pada masa lampau, sebuah karya ilmiah muncul dan terpendam dalam otak pengarangnya.

Transmisi ilmu yang terkandung bisa terwujud berkat kreatifitas tangan para penulis dengan susah payah menulis dan menyalinya. Akan tetapi, pada saat itu tulisan yang dihasilkan tidak tampak nilai harta atau penghargaan bersifat materi kecuali hanya pujian yang tertuju pada pengarangnya. Melalui potret sistem yang berlaku pada saat itu, kita bisa menarik kesimpulan bahwa sebuah afirmasi terhadap karya ilmiah adalah hak yang bersifat immateri (maknawi) bagi penciptanya atau pengarangnya.

Pada dasarnya, nilai harta pada sesuatu muncul dan ada bergantung pada pandangan umum masyarakat (urf al ijtima'i), baik kita memahami harta sebagaimana mazhab Hanafi yang mendefinisikan harta adalah merupakan benda atau barang yang berwujud yang boleh diawasi dan diambil manfaat darinya. atau kita mengikuti jumhur ulama' yang menkonsepsikan harta secara definitif sesuatu yang punya nilai baik pada barang yang berwujud atau kepada barang yang tidak berwujud. Contoh yang paling mudah untuk kasus ini adalah ulat sutra, dulu banyak orang memandang sebelah mata dan tidak menganggapnya sebagai komoditi. hal itu bisa terjadi mungkin disebabkan ketidaktahuan mereka manfaatnya atau mungkin juga mereka belum memeliki peralatan yang memadahi untuk mengolah sutra. Sehingga jual beli ulat sutra tidak masyru'. Namun seiring berjalanya waktu dan pergantian generasi orang mulai mengetahui manfaat ulat sutra dan berusaha mengeksploitasinya. bersamaan dengan itu jual beli ulat sutra pun disyariatkan dan ia menjadi komoditas yang potensial.

Dari uraian diatas, dapat difahami bahwa urf al ijtima'i memainkan peranan penting dalam menentukan harta dalam islam. Dengan syarat urf tersebut mematuhi segala ketentuan syara'. Imam al-Sayuutii dalam karyanya asybah wa annadhoir berkata "setiap apa yang disebut dalam syara' secara mutlak tanpa ada penentu dari bahasa maupun syara' itu sendiri, maka dikembalikan kepada urf", Sedangkan menurut urf harta itu adalah sesuatu yang punya nilai baik pada barang yang berwujud atau kepada barang yang tidak berwujud, dan nilai tersebut diukur pada manfaat barang tersebut.

Dalam anggapan manusia pada umumnya, harga buku tidak lebih dipandang dari segi harga tinta, kertas dan jerih payah penulis dalam menulisnya. tetapi dibalik itu sebenarnya terdapat nilai yang sangat berharga, Seperti khidmah terhadap agama, memberikan solusi-solusi ilmiah terhadap kebuntuankebuntuan, memberi kenikmatan kepada pembaca sebuah kebenaran ilimiah, mengurai benang kusut sebuah pemikiran atau faham. Dalam ranah ini para intelektual akhirnya berlomba-lomba, sehingga karya ilmiah menjadi sangat berharga dan sangat potensial dilihat dari segi ekonomi dengan tetap melihat hukum permintaan (Qonun arld wa tholab).

Meski demikian, bukankah ketika seseorang membeli buku tentu buku tersebut menjadi miliknya dan ia berhak memanfaatkan buku itu sepenuhnya, 
seperti memperbanyak atau mengkopi kemudian menjualnya. Untuk menjawab permasalahan ini, maka kita harus terlebih dahulu mengetahui bahwa sebenarnya aqad jual beli jatuh kepada nilai ilmiah(ilmu) yang terkandung dalam buku. karena itu memang yang menjadi tujuan orang membeli buku. oleh karena ilmu adalah sesuatu yang bersifat immateri dan tidak bisa diserah terimakan kecuali mengunakan wadah dan wadah itu adalah buku. Maka pada akhirnya yang menjadi obyek aqad jual beli adalah buku itu sendiri. dan secara tidak langsung nilai ilmiah (ilmu) yang ada dalam buku ikut terbeli tabi' terhadap buku.

Buku menjadi penentu batas nilai ilmiah (ilmu) yang dimiliki pembeli, penerbit akan memiliki hak mencetak jumlah yang disepakati dengan penulis. dan tidak boleh mencetak diatas yang sudah disepakati begitu juga konsumen dengan hanya berpegang kepemilikan terhadap buku. sebab sebagaimana keterangan diatas, bahwa aqad jual beli itu secara asl jatuh terhadap buku dan isi buku secara tabi'. Sehingga pembeli atupun penerbit memiliki secara penuh terhadap buku tetapi tidak dengan isi buku dan ia tidak boleh beranggapan dengan membeli telah menghilangkan hak yang dimiliki pengarang atas isi buku.

Majma' fiqih al islami sebagai badan Fiqih dunia yang bernaung dibawah OKI dalam muktamarnya di Kuwait pada tanggal 10-15 desember 1988 Memutuskan hak karya cipta dilindungi secara syara' dan bagi penciptanya memiliki hak tasarruf dan tidak boleh bagi yang lain berbuat kriminal terhadap hak tersebut.

Mengacu pada pemaparan al Buthi dan keputusan Majama' fiqih al-Islami, bukan pemilik buku tidak memiliki hak menggandakan atau mengkopi isi buku apalagi untuk dikomersialkannya. Lalu bagaimana dengan memfotocopynya, untuk digunakan sebagai materi bahan ajar atau tugas dan sebagainya. Dalam tinjaun fiqih islam, hukumnya tidak boleh kecuali ada izin atau ketika ada dzon qowi (prasangka yang kuat) ridlo dari pemiliknya serta tidak ada unsur merugikan maka diperbolehkan.

Mengkaji masalah hak cipta dalam tinjauan hukum Islam, harus dimulai dari pandangan Islam terhadap haq itu sendiri. Haq menurut Mustofa Zarqa' didefinisikan : "Kekhususan yang diakui oleh syariat Islam, baik itu berupa otoritas atau pembebanan".

Dengan demikian ini mencakup antara lain :

1) Hak Allah yang dibebankan kepada hambanya, seperti shalat, puasa dan zakat;

2) Hak sipil seperti hak untuk memiliki atas benda

3) Hak sosial, seperti hak orang tua kepada anak dan hak suami terhadap isteri;

4) Hak Publik seperti kewajiban negara untuk melindungi rakyatnya;

5) Hak berkaitan dengan harta seperti nafkah;

6) Hak yang berkaitan dengan otoritas seperti perwalian 7) Hak asasi yang mencakup hak untuk hidup bebas.

Kalangan ulama kontemporer bersepakat bahwa hak-hak cipta itu menurut syari'at terpelihara. Para pemiliknya bebas memperlakukan hak cipta itu sekehendak mereka. Tak seorang pun yang berhak melanggarnya, namun dengan syarat, jangan sampai dalam karya-karya tulis itu ada yang melanggar syari'at Islam yang lurus. Itulah yang menjadi keputusan akhir dari Lembaga Pengkajian Fiqih Islam yang lahir dari Organisasi Muktamar Islam pada pertemuan kelima di Kuwait tahun 1409 H, bertepatan dengan tahun 1988 M.

Seorang penulis berhak memberikan atau tidak memberikan hak cetak. Dia juga yang berhak membatasi jumlah oplah yang akan dicetak. Penerbit yang 
mencetak dan memasarkan buku tersebut hanya berfungsi sebagai wakil dari penulis untuk memenuhi hak-haknya dari pihak yang berhak mengambil keuntungan.

Dalil-dalil Syariat yang Menunjukkan Sahnya Menjual Hak-hak Cipta, antara lain:

1) Dalil mencari kemaslahatan. Pendapat yang menyatakan bahwa hak cipta penulisan itu bernilai dan layak dipasarkan dapat melanggengkan kemaslahatan umum. Dalam arti, dalam diharapkan keberlanjutan pengkajian ilmiah dan mendorong para ulama dan ahli ijtihad untuk melanjutkan penelitian mereka, sementara tulisan dan hak cipta mereka tetap terpelihara dari permainan orang yang tidak bertanggung-jawab. Syari'at Islam diturunkan untuk merealisasikan kemaslahatan dan menghindari kerusakan. Dimana ada kemaslahatan, di situ ada ajaran Islam. Aunur Rohim Faqih menyatakan dalam bukunya yang berjudul HKI, Hukum Islm dan Fatwa MUI :

Kewajiban menjaga harta sebagaimana yag diungkapkan oleh Al-Gazhali merupakan salah satu prinsip maqashid al-syari'ah. Maqashid al-syari'ah adalah tujuan utama Allah menetapkan hukum-hukumnya, adapun tujuan tersebut adalah untuk terwujudnya kemaslahatan hidup manusia baik di dunia maupun di akhirat. ${ }^{14}$

2) Kebiasaaan terjadinya persoalan ini dan kesepakatan kaum Muslimin melakukannya merupakan dalil bahwa mereka sudah mengetahui dibolehkannya urusan itu. Jelas bahwa kebiasaan itu memiliki pengaruh pada hukum syari'at, kalau tidak bertentangan dengan nash. Karya ilmiah itu memiliki nilai jual secara terpisah, tidak berkaitan dengan intelektualitas penulisnya. Itu merupakan hak yang permanen, bukan sekedar hak semata. Berarti hak itupun bisa berpindah dan bisa dijual-belikan, bila dirusak atau dihilangkan, harus dipertanggung-jawabkan dan diberi ganti rugi.

3) Pendapat yang dinukil dari sebagian ahli hadits yang membolehkan mengambil upah dalam menyampaikan atau mengajarkan hadits. Para ulama ahli hadits biasanya membolehkan siapa saja yang mereka kehendaki untuk meriwayatkan hadits-hadits mereka, dan melarang sebagian lain yang tidak mereka kehendaki, bila orang-orang tersebut dianggap tidak memiliki kompetensi di bidang periwayatan. Dari sebagian ulama ahli hadits juga diriwayatkan dibolehkannya mengambil upah dalam mengajarkan hadits, diqiyaskan dengan dibolehkannya mengambil upah dalam mengajarkan al-Qur'an.

Ibnu Shalah menyatakan; "Barangsiapa mengambil upah dari mengajarkan hadits, riwayatnya menjadi tidak bisa diterima menurut sebagian imam ahli hadits."

Sementara Abu Nuaim al-Fadhal bin Dzukain dan 'Ali bin 'Abdul-'Aziz al-Makki dan para ulama lainnya masih membolehkan mengambil upah dari penyampaikan hadits, karena serupa dengan mengambil upah dari mengajarkan al-Qur'an dan sejenisnya. Hanya saja dalam kebiasaan ahli hadits hal itu dianggap merusak citra. Bahkan pelakunya bisa dicurigai, kecuali bila ada alasan tertentu yang mengiringinya sehingga bisa dimaklumi. Seperti yang disebutkan bahwa Abul-Husain bin an-Naqur melakukan perbuatan itu karena

${ }^{14}$ Aunur Rahim Faqih dkk, HKI, Hukum Islam dan Fatwa MUI, Graha Ilmu, Yogyakarta, 2010, hal. 26 
Abu Ishaq memberikan fatwa dibolehkannya mengambil upah dari mengajarkan hadits.

Kalau kebiasaan para ulama pada masa itu menganggap mengambil upah dari mengajarkan hadits itu termasuk perusak citra, sekarang kebiasaan sudah berubah karena perbedaan zaman dan tempat. Sehingga hukum yang didasari kebiasaan tersebut juga bisa berubah.

4) Qiyas seorang produsen atau pembuat barang bisa menikmati hasil karyanya, memiliki kebebasan dan kesempatan untuk orang lain memanfaatkannya atau melarangnya. Maka demikian juga seorang penulis, karena ia telah menyatukan antara membuat dengan memproduksi satu karya ilmiah, telah berkonsentrasi dan mengerahkan waktu serta tenagannya untuk tujuan itu.

5) Kaidah saddudz-dzara-i' (menutup jalan menuju haram). Karena pendapat yang menyatakan dibolehkannya menjual hak cipta penulisan mengandung upaya memberikan dorongan bagi para pemikir dan para ulama untuk semakin produktif dan semakin giat melakukan penelitian ilmiah. Bahkan juga bisa memompa semangat mereka untuk menciptakan hal-hal baru dan melakukan reformasi. Apalagi mereka atau sebagian besar mereka hanya memiliki bidang ilmiah itu sebagai sumber penghasilan mereka. Menggugurkan nilai jual dari karya tulis itu sendiri bisa menyebabkan mereka meninggalkan pekerjaan tersebut dan beralih ke pekerjaan lain untuk menjadi sumber penghidupan mereka. Hal itu tentu saja menyebabkan umat kehilangan kesempatan mendapatkan hasil dari karya mereka, bahkan menyebabkan matinya gairah untuk menulis pada banyak kalangan peneliti ilmiah. Jelas yang timbul adalah kerusakan yang besar.

6) Dasar ditetapkannya nilai jual adalah adanya mutu yang dibolehkan syari'at. Mutu dari karya ilmiah bagi umat masa kini dan masa mendatang amat jelas sekali. Kalau para ulama telah mengakui nilai jual dari berbagai fasilitas yang lahir dari sebagian jenis hewan, seperti ulat misalnya, atau kicauan burung, suara beo misalnya, manfaat atau fasilitas yang berasal dari karya tulis tentu lebih layak lagi memiliki nilai jual. Manfaat yang seharusnya dinikmati oleh pemiliknya. Manfaat itu lebih layak diperhatikan, karena lebih besar hasilnya dan lebih banyak faedahnya.

7) Di Indonesia Majelis Ulama Indonesia (MUI) telah mengeluarkan fatwa MUI Nomor: 1/MUNAS/VII/MUI/15/2005 Tentang Perlindungan HKI, di mana dasar pertimbangan filosofis dikeluarkannya Fatwa MUI ini adalah HKI merupakan bagian dari harta yang dimiliki oleh pencipta.

Dalam UUHC pasal 3 mengatur sebagai berikut :

(1) Hak cipta dianggap sebagai benda bergerak.

(2) Hak cipta dapat beralih atau dialihakan baik seluruh maupun sebagian karena : (1) Pewarisan, (2) Hibah, (3) Wasiat, (4) Dijadikan milik negara.

Karya cipta merupakan kemaslahatan umum yang hakiki, oleh sebab itu, hak para penciptanya perlu dilindungi dengan Undang-undang dalam rangka menjaga hak penciptanya. Penalaran ini sesuai dengan jiwa dan tujuan syari'at untuk mengambil maslahat dan menolak madlarat.

Hukum Islam dalam kaitannya dengan hak, menetapkan langkah-langkah hukum sebagai berikut:

1. Memberikan hak kepada yang berhak. Bila itu hak Allah, maka harus dipenuhi dengan mengikuti aturan yang telah diberikan oleh Allah. Semisal shalat harus 
dipenuhi oleh mereka yang kewajiban sesuai dengan aturan yang ditentukan. Demikian pula zakat harus diberikan oleh mereka yang berkewajiban dan disalurkan kepada yang berhak, sesuai ketentuan yang ditetapkan.

2. Melindungi Hak Syariat Islam memberikan perlindungan kepada hak dari segala bentuk penganiayaan, kecurangan, penyalahgunaan dan perampasan. Di sini perlindungan yang diberikan pertama: berupa perlindungan moral, seperti keharaman meninggalkan ibadah wajib, keharaman mencuri, berzina, keharaman menipu dan memalsu, keharaman transaksi mengandung riba dan kewajiban menjunjung tinggai nilai-nilai masyarakat yang sesuai agama. Kedua adalah perlindungan hukum, setiap orang yang dizalimi boleh mengangkat masalahnya ke pengadilan untuk mendapatkan kembali haknya.

3. Menggunakan hak dengan cara yang sah dan benar. Setiap manusia diberi wewenang menngunakan haknya sesuai dengan yang diperintahkan dan diizinkan oleh syariat. Oleh sebab itu dalam menngunakan hak tidak boleh melapaui batas dan tidak boleh menimbulkan kerugian padapihak lain, baik yang sifatnya personal maupun publik. Suatu contoh meskipun dalam menggunakan hak miliknya seseorang mendapatkan jaminan hukum, tapi jangan sampai dalam mengguankan hak milik tersebut mencederai orang lain. Seorang penguasa meskipun diberi hak membelanjakan harta publik, ia tetap berkewajiban membelanjakannay sesuai peraturan dan ke jalan yang benar.

4. Menjamin perpindahan hak dengan cara benar dan sah. Hukum Islam melindungi perpindahan hak melalui prosedur dan cara yang benar, baik itu melalui transaksi seperti jual beli, atau pelimpahan seperti dalam kasus jaminan huang atau hak yang berkaitan dengan wewenang, berpindahnya hak perwalian dari orang tua ke anak sepeninggal orang tua.

5. Menjamin hangus/terhentinya hak dengan cara benar dan sah Hukum Islam melindungi hangusnya hak, atau terhentinya hak melalui prosedur dan cara yang sah, misalnya hangusnya hak suami isteri melalui perceraian atau pengguguran hak secara sukarela, seperti tidak menggunakan hak menuntut ganti rugi. Bagaimana dengan hak paten atau hak cipta, hak-hak yang disebutkan di atas telah mempunyai landasan dalil eksplisit yang cukup kuat, baik dalam al-Qur'an atau hadist Nabi. Namun semacam hak paten atau hak cipta, tidak mempunyai landasan nash yang eksplisit. Ini karena gagasan pengakuan atas hak paten dan hak cipta itu sendiri merupakan masalah baru yang belum dikenal oleh masyarakat terdahulu.

Pencurian atas hak cipta menurut hukum Islam juga bisa terancam hukuman. Dosakah pencurian atas hak cipta dalam tinjauan agama? Sejauh hak cipta merupakan hak yang harus dilindungi, maka mencurinya, secara lahir jelas sama dengan mencuri hak-hak lain yang terlindungi. Sejauh pencurian terhadap hak intelektual menimbulkan kerugian bagi pemilik hak tersebut, maka mencurinya jelas sama dengan menimbulkan kerugian materi lainnya terhadap orang lain. Yang jelas agama Islam melarang segala bentuk kedlaliman dan tindakan yang merugikan orang lain.

\section{SIMPULAN}

Dari pemaparan tentang hak cipta dalam perspektif hukum Islam maka dapat ditarik kesimpulan sebagai berikut: 
1. Hak Cipta secara yuridis normatif diakui dan dilindungi oleh hukum Islam yang menggunakan metode Qiyas, fatwa-fatwa Majelis Ulama dan dikuatkan oleh pendapat beberapa ulama.

2. Hak cipta menurut pandangan Islam adalah salah satu harta yang dimiliki oleh manusia dan merupakan salah satu harta yang harus dilindungi dan dapat dipertahankan oleh pemiliknya.

\section{DAFTAR PUSTAKA}

Aunur Rahim Faqih dkk. HKI. Hukum Islam dan Fatwa MUI. Graha Ilmu. Yogyakarta, 2010.

Beni Ahmad Saebani, Filsafat Hukum Islam, Pustaka Setia, Bandung, 2008.

Mahmud Syaltut, Tafsir Al-Qur'an, Dar Al-Qalam, Kairo

Muhammad Firmansyah, Tata Cara Mengurus HAKI.(Hak atas Kekayaan

Intelektual). Visi Media. Jakarta, 2008.

OK. Saidin. Aspek Hukum Hak Kekayaan Intelektual, Raja Grafindo Persada, Jakarta, 2006.

Ramdlon Naning. Perihal Hak Cipta, Liberty. Yogyakarta, 1982.

Satjipto Rahardjo. Aspek Sosio-Kultural dalam Pemajuan HKI, makalah dalam seminar nasional penegakan hukum HKI dalam konteks perlindungan ekonomi usaha kecil dan menengah, Semarang, 2000.

Yusuf Al-Qardhawi. Islam dan Sekurelisme. Pustaka Setia. Bandung, 2006. 